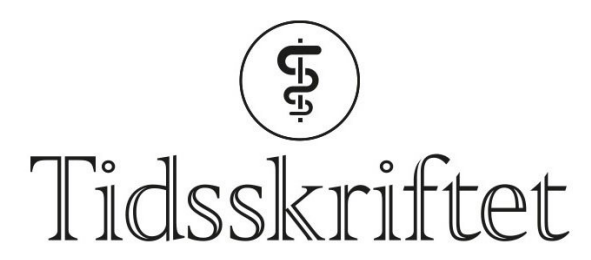

DEN NORSKE LEGEFORENING

\title{
Laparoskopisk eller åpen kirurgi ved magekreft?
}

FRA ANDRE TIDSSKRIFTER

PETTER MORTEN PETTERSEN

Tidsskriftet

Kikkhullskirurgi gir like gode resultater som åpen kirurgi ved ventrikkelcancer, viser en ny studie.

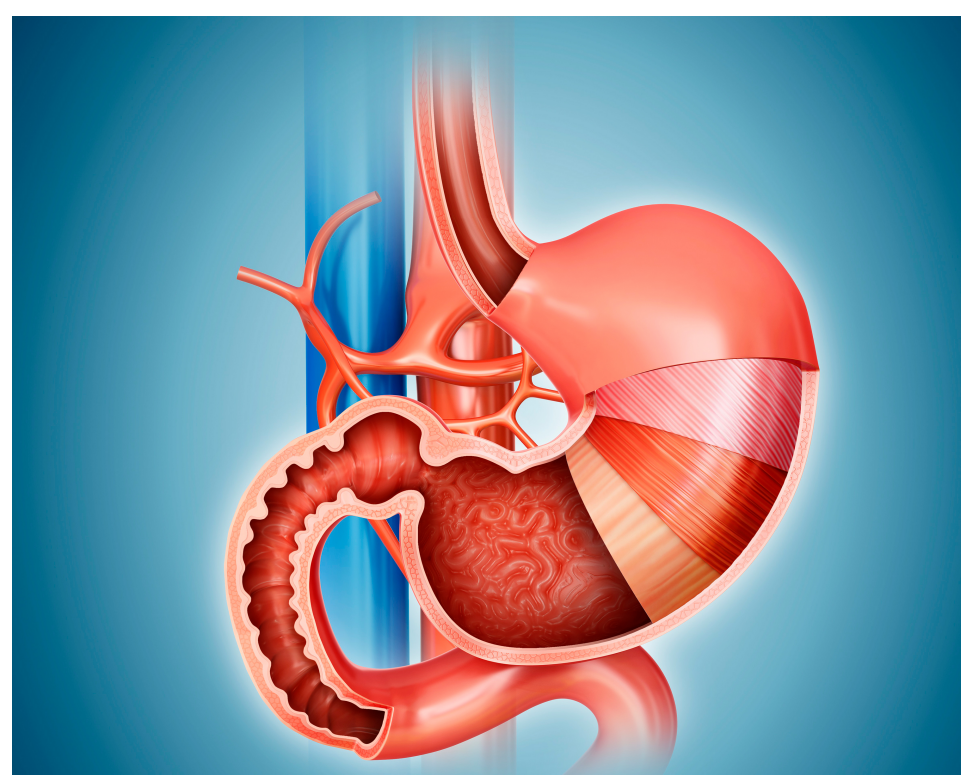

Illustrasjonsfoto: Science Photo Library / NTB Scanpix

I en randomisert klinisk studie i Kina ble noe over 1 ooo pasienter med lokalavansert kreft i nedre del av magesekken randomisert til enten laparoskopisk kirurgi eller åpen kirurgi (1). Alle pasientene fikk deler av magesekken fjernet. Tre års sykdomsfri overlevelse var den samme, dvs. henholdsvis $77 \%$ og $78 \%$.

- Resultatene er ikke overraskende og støtter bruken av laparoskopisk tilgang som onkologisk likeverdig med åpen kirurgi, sier Tom Mala, som er overlege ved Avdeling for gastro- og barnekirurgi ved Oslo universitetssykehus, Ullevål.

- For studiens generaliserbarhet må man forutsette at prosedyrene er utført av erfarne kirurger, sier han.

Data fra et norsk kvalitetsregister fra 2016 viser at omtrent halvparten av pasientene som ble operert for kreft i magesekken, ble operert med laparoskopisk kirurgi, men andelen varierte mellom helseregionene. Mala anslår at andelen pasienter som blir operert med 
laparoskopisk kirurgi for kreft i magesekken, er enda større i dag.

LITTERATUR:

1. Yu J, Huang C, Sun Y et al. Effect of laparoscopic vs open distal gastrectomy on 3-year disease-free survival in patients with locally advanced gastric cancer. JAMA 2019;321:1983-92. [PubMed][CrossRef]

Publisert: 28. august 2019. Tidsskr Nor Legeforen. DOI: 10.4045/tidsskr.19.0407

(C) Tidsskrift for Den norske legeforening 2020. Lastet ned fra tidsskriftet.no 